\title{
BUILDING THE INDEX OF RESILIENCE FOR ISLAMIC BANKING IN INDONESIA: A PRELIMINARY RESEARCH
}

\author{
Fanny Arumsari ${ }^{1}$ \\ Dimas Bagus Wiranatakusuma² \\ Abu Umar Faruq Ahmad ${ }^{3}$
}

\begin{abstract}
The 2007-2008 global financial crises had brought severe financial instability in financial institutions, and since then it became more complex and irreparable. Therefore, it has become inevitable to examine various tools that can monitor resilience of these financial institutions, especially the banking system that plays significant role in economic development of a country. Although Islamic banking operates in the same financial environment, its distinguishing features and fundamental differences demand different treatment in building resilience. The scope of existing literature of banking surveillance tools is either to some extent, mostly limited to banking sector in general, or it is dominated by partial developments. Hence, there is a significant gap that lies in the literature to address the specificity of Islamic and conventional banking surveillance tools analysis to build resilience that can contribute to reduce the span of financial instability in a country. This study seeks to explore to fill in this gap in Indonesian jurisdiction. The study finds that optimum resilience level of Shari ah banking in Indonesia exists in specific range as a result of the contribution that is made by each and every indicator. The study also attempts to find a way to trace some indicators that could effectively contribute to prevent the instability of Shariah compliant banking system in Indonesia.
\end{abstract}

Keywords: Shari'ah banking, resilience, index, Islamic banking, Indonesia

\footnotetext{
${ }^{1}$ Researher at International Program for Islamic Economics and Finance, Department of Economics, Faculty of Economic and Business, Universitas Muhammadiyah Yogyakarta. Corresponding Author: fannyarumsari@gmail.com

${ }^{2}$ Lecturer at International Program for Islamic Economics and Finance, Department of Economics, Faculty of Economic and Business, Universitas Muhammadiyah Yogyakarta. Corresponding Co-Author: dimas_kusuma@umy.ac.id

${ }^{3}$ Associate Professor at Institute of Policy Studies, Universiti Brunei Darrussalam, email: umar.ahmad@ubd.edu.bn or aufahmad@gmail.com
} 


\section{INTRODUCTION}

As a Divine religion and being a complete code of life, Islam has special and unique characteristics while it is not only all-inclusive but also universal. Allinclusive means the Islamic Shari'ah combines all aspects of human life, and as such it discusses all matters pertaining to both rituals ('ibadat) and social behaviors or civil transactions (mu'amalat). The tenets of universal Islamic Shari ah can be applied in any time and and place until the Day of Judgment. This universality is similarly applicable in the fields of mu'amalat. Besides, being broad and flexible, the principles and practices of muamalat do not discriminate between Muslims and non-Muslims, and as such in terms of mu'amalat, nonMuslims obligations are considered Muslims' obligation and vice versa.

Islamic economic system is a part of Muslims' life in an effort to implement the teachings of Islam in economic activities. According to Yuliadi (2007), this system is an important aspect of an integral and comprehensive Islamic system to create a better human life. Alignment and balance between the horizontal and vertical aspects can guarantee the human's lives and the universe to walk in harmony and continuous prosperity in this world and the hereafter. By applying the system one may automatically fit unanswerable questions in economy as well as in human life.

The absence of Shariah managemnet and its application in economic system might have indirect links with the financial crisis in the Asian financial crisis of 1997-1998. Perhaps, it is because the riba or interest based commercial dealings caused money creation, while, gharar or uncertainty and excessive risks, or maysir or gambling and games of chance in secondary were ineviTable, which resulted in bringing the financial crisis. It happened as Asian financial crisis of 1997-1998 spent extraordinary cost to countries for bailing out banks as much as 55\% of gross domestic products (GDP). ${ }^{4}$ Albeit, this does not include the cost to depositors and borrowers of wider interest rate spreads from bad loan of balance sheets that can push down economic growth of countries involved.

Given that, the demand for financial stability and a sound and resilient economic environment have been increased, , and are becoming an interesting phenomena in both developing as well as developed countries. The only alternative solution remains is to test the robustness of Islamic economics and finance that are based on the rules and tenets of Shari'ah.

4 Caprio and Klingebiel 2003 in World Development Indicator, 2009. 
In order for finding solutions to these issues, several international forums that have been devoted to provide crisis prevention namely, the World Bank, and International Monetary Fund (IMF) came forward by introducing The Financial Sector Assessment Program (FSAP) in 1999 in the wake of the Asian financial crisis. The program brings together Bank and Fund expertise to help countries reduce the likelihood and severity of financial sector crises.t Other international forums that have been instrumental to solve the crisis were the Basel Committee on Banking and Supervision (BCBS), Islamic Financial Services Board (IFSB), Financial Stability Board (FSB), the International Association of Insurance Supervisors (IAIS), and International Accounting Standard Board. Generally, the aim of these forums is to assess regularly the strength and weaknesses of financial systems to enhance financial stability.

The study undertaken by the authors from Indonesian jurisdiction on the relevant area shows that this country is classified as bank backed asset where more than $70 \%$ of the assets in financial institutions dominated by banking. (figure 1.2) According to Basurto \& Padilla (2006), a robust and good financial system is a key for macroeconomic stability in terms of supporting, savings and efficiency in allocating resources and investment opportunities. Hence, it is important to conduct surveilance as a prior step to catch up financial system stability. According to Bank Indonesia, the resilience of financial system can be defined through several conditions, as described as follows: (i) when financial system is able to allocate resources and to absorb shock occurs, which can prevent surprises in the real sector, (ii) when financial system is still capable of running intermediation function, execute payments and redistribute risk properly if there is an interference with the economy, and (iii) when price decision, allocation of funds and the risk management in financial system are running well and supporting economic growth.

The stability of the financial system itself cannot be achieved without the in-depth understanding of any components inside the system. The financial system consists of a number of financial institutions, a set of financial markets, the financial system infrastructure, and a number of rules and procedures that guarantee the savings and transactions of loans are running well. Here financial system stability cannot be separated from financial institutions, soundness and financial market stability. Banking is one important part that supports financial system stability. A strong banking system and resilience of banking system are the foundation for sustainable economic growth, as banks are at the center of the credit intermediation process between the savers and investors (BIS, 2009). the 
existence of both banks individually and the entire system is a requirement for sustainable economic growth.

Islamic finance, with the banking system part and parcel of it, is one of the fastest growing segments of the global financial industry. In some countries, it has become systematically important, while in many others, it is hard to be ignored. Though, Islamic finance encompasses banking, insurance, leasing, investment funds, micro finance, Sukuk (Islamic securities) and equity and so on Their assets mainly generate from banking and Sukuk sectors. These two sectors of Islamic finance represent about $95 \%$ of the total global Islamic finance assets. It is estimated that the size of Islamic banking industry at global level was nearly \$882 billion as at the end of 2014 with average growth rate of $14 \%$ per year during 2010-2014. ${ }^{5}$ This is about two to three times faster than the rate at which conventional bank grew over the same period, due in part to the global financial crisis.

Despite these developments of Islamic banking industry, it is worthy of note that although the structured literature that mainly focused on micro prudential surveillance there is a dire need of comprehensive discussion on resilience-based supervision. Generally, surveillance authorities apply either macro prudential or generic surveillance framework procedure for both institutions offering Islamic financial services (IIFS) and conventional banks. One of well-known tools in this regard is capital, asset quality, management, earnings, liquidity and. CapitalManagement-Earnings-liquidity-sensitivity (CAMELS) rating system, which is generally appropriate, but still less adapted to the specific risks by Islamic banks (IBs) and IIFS, particularly regarding Shari'ah compliance, capital adequacy, asset quality, and liquidity. Moreover, the present literature covers partial Islamic banking (IB) soundness variables, by using non performing financing (NPF), capital adequacy $r$ atio (CAR), return on asset (ROA) to gain understanding about IB resilience. Gunadi (2013) provided comprehensive understanding about banking resilience even financial system stability by using financial system stability index (FSSI). However, the discussion has been centered toward assessing the banking resilience and stability rather than specific for IIFS and micro prudential perspectives.

Islamic banking has some distinguishing features that made it unique and different from its conventional counterparts in several ways. Conventional banks' (CBs) intermediation is largely debt-based with pre-specified interest rate and

${ }^{5}$ World Islamic Competitiveness Report, EY, 2016 
allows for risk transfer, while IIFS and IB's intermediation is asset-based and centers on risk sharing (Mejía, 2014). In running sale and lease contracts, IIFS must have underlying assets. It makes IIFS more resilient during the global financial crisis compare to its conventional counterparts.

A recent theoretical study carried out by Farahani, Guzardi et al., 2012) found positive and significant relationship between Islamic banking development and economic growth. While the expansion of IBs is expected to support growth, it still stances challenges in terms of competition, size, standardisation, regulation, and cost structure. Standardisation and regulation of IBS is one of potential challenges to be explored, as it can make effective surveillance and give directions for authorities as well as institutions themselves to promote stability and resilience that can contribute to economic growth. Moreover, the urge for tools for IBs to do supervision and surveillance is categorised as strategic issue in the developments of IBs and IIFS in Indonesia. ${ }^{6}$

In recent developments, composite indicators $(\mathrm{Cls})$ that compare country performance are increasingly recognised as a useful tool in policy analysis and public communications. According to Bandura, (2006) the number of $\mathrm{Cls}$ in existence around the world is growing year after year in academic circles, the media and among policymakers. He cites more than 160 composite indicators that provide simple illustration of complex and sometimes elusive issues in wideranging fields, e.g., environment, economy, society or technological development. This can be used not only in macro level, but also in micro level, such as bank. It is quite rare for IB having tool such as internal composite Index compare to CB.

According to the description above, this study attempts to fill the gap in term of the lack of comprehensive tools for IB to enhance resilience. Analyzing Islamic banking resilience supervision in Indonesia is interesting effort, as this country is the biggest Muslim population in the world and has complete periodical economic situation. This economic situation refers to normal, recession, and crisis in the last two decades.

Hence, this studyis going to provide tools as a surveillance the resilience of IB in Indonesia. The study uses a constructed index to supervise resilience of Islamic banking in Indonesia. The data used are high-frequency data (monthly data) that reflect the behaviour of the financial institutions, particularly IB. This study has adapted the specific characteristics of Shari ah banking intermediation, which is

\footnotetext{
${ }^{6}$ Roadmap perbankan syariah Indonesia, 2015-2019
} 
asset based and centers on risk sharing. Methodology used is normalisation of indices pre-and post-year by comparing current related variables of idyosyncratic risk in banking with pre-and post-year. The proportion of every index forming financial institutions assumed to be equal.

The study contains several sections, which are as follows: Section 1 provides the background and introduction to the study. Section 2 covers literature review of composite indicators $(\mathrm{Cl})$ formation any indicator related to stability of financial institutions. Section 3 explains the data selected, steps for constructing SHABAR index, as well as construction model of SHABAR Company index. While section 4 analyses the results of SHABAR index formation. It also discusses the implications and key issues in building IB' resilience sensitivity analysis of each indicator on the index, as well as future index projection. Section 5 concludes and offers a way forward for SHABAR index studies followed by appendices.

The scope of the study has some limitations to the extent that it analyses the problems that focused on (i) all IBs ${ }^{7}$ listed in website of Bank Indonesia after the enactment of Islamic Banking Act No. 21 of 2008 (hereiafter 'The Act', (ii) The data spans from January 2010 to December 2016, monthly time series data, (iii) indicators used to build Shari'ah banking resilience (SHABAR) index based on trinity of financial system stability from Bank Indonesia, (iv) indices constructing resilience are related to idiosyncratic risk of Shari ah banking (micro level)

1. To reflect to research problems to be solved in this study, the overall quest of the research questions can be formulated as follows: How to construct an index for monitoring the resilience of Islamic banking in Indonesia?

2. To what extent was the resilience of Islamic banking in Indonesia?

3. How does each indicator of the index contribute to the resilience of Islamic banking in Indonesia?

\section{METHODOLOGY}

\subsection{Research Variable and Data Type}

Shari ah Banking Resilience (SHABAR) Index is arranged based on the trinity of financial system stability by using 11 indicators classified into 3 major categories, namely Islamic Banking Institution Pressure Index, Islamic Banking Institution Intermediary Index, and Islamic Banking Institutions; Efficiency Index.

\footnotetext{
${ }^{7}$ Institutions offering Islamic Fiinancial Services, Analog with Islamic Banking
} 
Variables reflecting degree of pressure from IBs and IIFs are NPF, CAR, ROA, and delta liquidity $(\Delta \mathrm{L})$. Variables reflecting Islamic banking intermediation are the spread financing margin to DPK margin (SFTD), Gap financing to deposi ratio (Gap FDR), financing to GDP ratio (F/GDP), and gap gross domestic product (Gap GDP). Variables reflecting Islamic banking efficiency are net operating margin (NOM), operational efficiency ratio (OER) or BOPO ratios, cost to income ratio (CIR), and overhead cost (OHC to total operating revenue.

Data used in this study are secondary monthly time series data, starting from January 2010 until December 2016. The usage of monthly data based on technical statistics consideration is related to degree of freedom problem and limitation of publication, while the selection time period from 2010 until 2016 is based on the period after being issued the Act. This regulation practice has certainly undergone evolutionary episodes of juridical legal base not only for the growth and development of Shariah banking, but also for possibile developments of introducing Islamic windows or subsidiaries by conventional interest-based banks in Indonesia. It was assumed that 1 year is effective period of socialisation of regulation, where another 1 year is to build up complete economic situation in Indonesia (normal-recession-crisis) which is expected to make this study applicable for such future situation.

\subsection{Data Collecting Method and Sources}

A documentary review (documentary research method) was used in collecting relevant information in this study on the subject. Payne and Payne (2004) describe the documentary method as the techniques used to categorise, investigate, interpret and identify the limitations. According to Bailey (1994), documentary research method refers to the analysis of documents that contain information about the phenomenon the researchers wish to study.

Data were obtained from various sources published periodically by (i) Bank Indonesia (BI), (ii) Financial Services Authority (OJK) and (ii) Central Bureau of Statistics (BPS), such as Indonesia Islamic Banking Statistics (SPSI) and Indonesia Financial Economic Statistics (SEKI) reports. This study also obtained relevant information from official websites, magazines, journals and articles regarding the relevant study. 


\subsection{Data Analysis Model and Hypothesis Testing}

The study used indexing method with standardisation normalisation basic year approach to analyse SHABAR index. The purpose of using this method is to achieve the key research objectives and find possible answers to the existing problem formulation. Also, because this method normalises the outliers in data series, paves the way for making adjustments in scale, facilitates the transformation and aggregation of abnormal data. Another key reason for using this method is that it enables to illustrate complex and sometimes elusive issues in wide range of fields, especially in banking system.

\section{Step 1: Developing a Theoretical Framework}

1) Complex Adaptive System Theory

Complexity results from the inter-relationship, inter-action and inter-connectivity of indicators within and between a system as well as its environment. Many natural systems (e.g., brains, immune systems, ecologies, societies included politic and economic) and increasingly, many artificial systems (such as parallel and distributed computing systems, artificial intelligence systems, artificial neural networks, evolutionary programs) are characterised by apparently complex behaviours that emerge as a result of often nonlinear spatio-temporal interactions among a large number of component systems at different levels of organisation. These systems have recently become known as Complex Adaptive Systems (CAS). ${ }^{8}$

Banking system as part of economy face same characteristics of complex behawviour from nonlinear interactions among a large number of indicators at different levels that emerge from the whole system of even economy and a country. Constructing the resilience of Shariah banking can be done by feasible monitoring process of every indicator in the banking system itself, so that every movement can be measured and advanced with a quick and precise decision.

${ }^{8}$ Ibid 


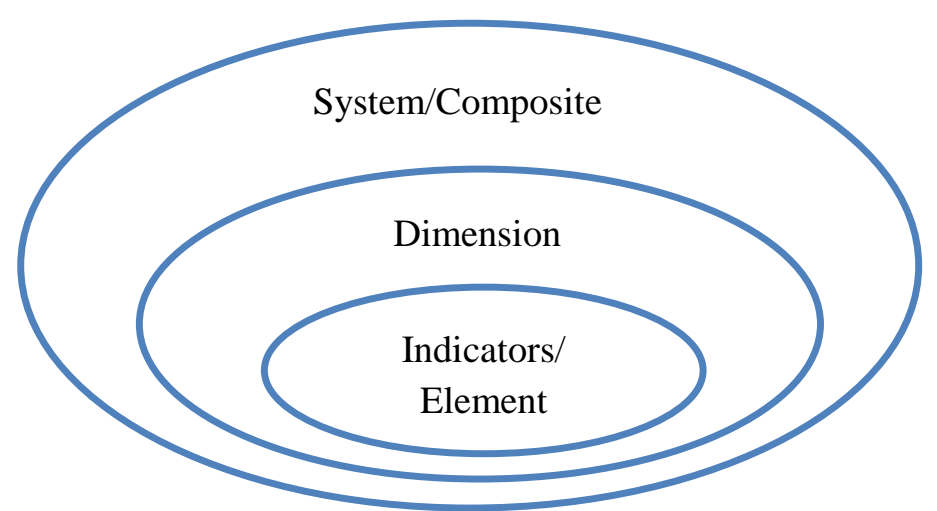

Source: Authors' own, 2014

Figure 2.1

2) Financial Cycle Phase Theory

In the financial cycle, the build up phase is the stage of source formation interference. In this phase, market participants tend to take advantage of conditions in order to achieve the greatest profits even though the stringent prudential rules may apply. This phase has been illustrated in the upward or upswing cycle segment (Figure 3.1). Under these conditions, systemic risk measurement needs to be focused on measurements of financial system imbalance, and measurements against stress indicators that show signs of the fact that the financial cycle are approaching to its peak, which is interpreted as already excessive risk-taking behaviour.

Imbalances were detected here are related with to the behaviour of bank's' procyclicality in lending. establishment of financial cycle indicators, as was described previously is also considered also as one of the efforts to detect imbalances in the financial system because ofowing to the perception of market participants against economic conditions, as far as the risk-taking behavior is concerned and behavior take its risks. Furthermore, the source of the materialized materialised disturbance becomes a risk that will spread in the propagation phase or propagation mechanism. That phase happens after and between the peak of the financial cycle until the cycle reaches basically or trough (Figure 3.1). In this phase, the problem occurs in one elements of the banking system tend to be transmitted to or propagated on sectors or other elements of the banking system. Therefore, the measurement of risk systemic in this phase generally use cross sectional indicators. Indicators the most needed in this case are indicators that indicate the relationship between physical exposures among financial system elements, including for every individual element of the financial system which is primarily a financial institution and corporation. 
The last phase is the systemic event phase or also called ss materialized shock. Thise phase is related to the financial crisis.

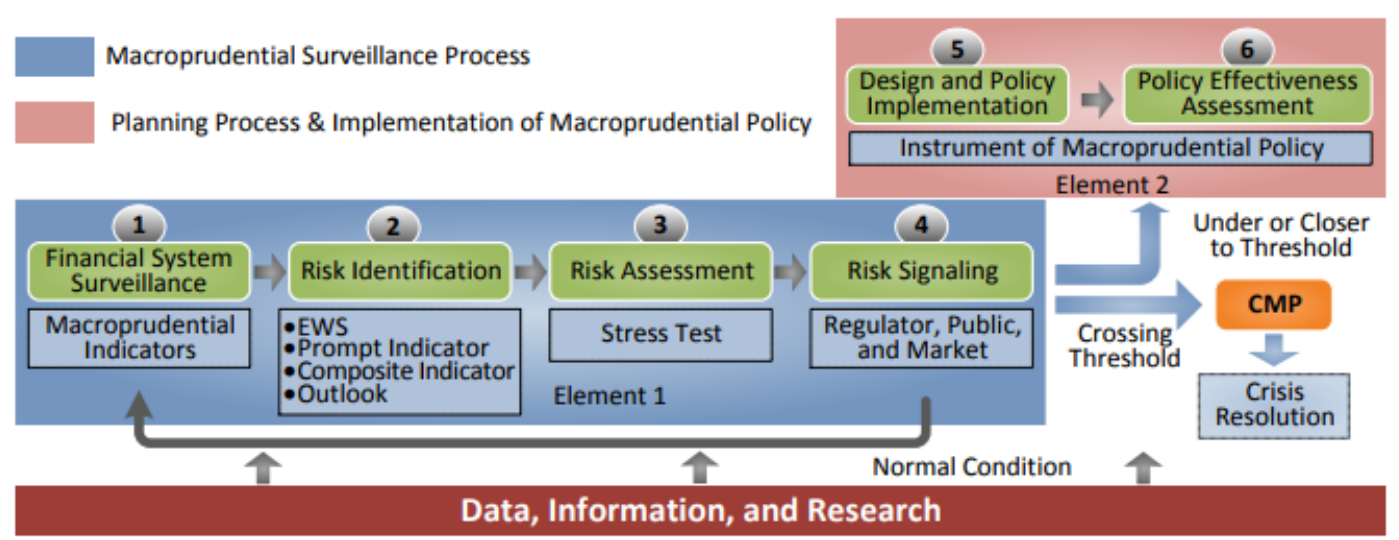

Figure 2.2

Conventional Macroprudential Framework in Bank Indonesia

The results of the data were collected in the past showed that the crisis generally occurs around 2 years after the peak of the financial cycle. Thus, systemic event is a very short period in the propagation phase due to the fact that shock and vulnerability occur and resulted in establishing systemic risk. After the systemic event occurs, the downswing segment formed can be U-shaped or $\mathrm{V}$-shaped. If it is U-shaped, downswing will last deeper and longer in the cycle finance, and will be accompanied by a long recovery period. This condition has the potential to have structural impacts on downswing. If it is V-shaped, downswing will take place in a shorter period and the recovery will also take place faster. In the financial cycle, systemic events just cannot happen because in the downswing segment market participants are in a position to automatically adjust its portfolio to reduce potential losses. It depends on the resilience of the elements of the financial system.

3) Defining Resilience and Signal Crisis

To determine the level of resilience of Shari'ah banking in Indonesia, the first step is to understand the flows of macroprudential framework in Indonesia in order to identify the risk embodied in the financial system, which potentially leads to create systemic system, realising how to deal with risksspread, through which channels the risks are spread out, and the precise momentum to release the particular instrument of macroprudential policy so the potential risks can be prevented and spread accross financial system, macroeconomic, and real sector (Ascarya et al., 2016). 
The study specifies to construct such index to monitor the financial system until risk signaling, which are the first four steps in conducting macroprudential surveillance process. Macroprudential policy appears in the critical points when crossing below or above the tolerated thresholds. Based on figure 3.3 it happens in fist step of financial system surveillance.

After determining the area of banking resilience, the next step is to determine the definition of resilience itself. This definition is made to focus the study's initial objectives and facilitate the identification as to whether the value of the index SHABAR exceeds its threshold or not. If the variable crosses the threshold, a signal is emitted, and as such it will determine whether the composite of Shariah banking is in a position of resilience or not. The definition of resilience is as follows:

The signal is constructed to be a binary variable where $S_{x_{t}}=(0,1)$. If the variable crosses the threshold, a signal is emitted $S_{x_{t}}=1$. Mathematically, it can be described,

$\left\{S_{x_{t}}=1\right\}=\left\{\left|x_{t}\right|>\left|x_{t *}\right|\right\}$

Meanwhile, if the indicator remains within its threshold boundary, it behaves normally and does not issue a signal, so $S_{x_{t}}=0$.

$\left\{S_{x_{t}}=0\right\}=\left\{\left|x_{t}\right|<\left|x_{t *}\right|\right\}$

In terms of defining crisis, the research borrows the SHABAR is as follows:

$\left\{C_{x_{t}}=0\right\}=\{S H A B A R$ Index $<$ Threshold $\}$

$\left\{C_{x_{t}}=1\right\}=\{$ SHABAR Index $>$ Threshold $\}$

Where:

$S_{x_{t}} \quad$ : Signal variable relating indicator $x_{t}$ in t-period

$x_{t} \quad:$ Value of indicator $x_{t}$ in $t$-period

$x_{*} \quad:$ Threshold of the indicator

$\bar{\partial}_{2 \text { years }}$ : Standard deviation of of $x_{t}$ in 2011

In addition, in taking a conclusive remark, it is important to notice the directional $\operatorname{sign}^{9}$ may vary depending on whether the indicators (leading indicators) at resilience level questions above are expressed in absolute terms. After that, it needs to obtain a binary time series of signal or no-signal observations.

Interpreting crisis and signal framework once the crisis and signal are defined, the evaluation criteria can be conducted by using matrix framework. Kaminsky, et Al.

${ }^{9}$ Loc.cit 
(1998) developed matrix crisis-signal framework by using 12 months as signal window horizon, which is as follows:

Table 2.1

The Performance of Individual Indicator by Matrix Crisis-Signal Framework

\begin{tabular}{|l|l|l|}
\hline \multirow{2}{*}{ Table of Statistical Error } & Actual \\
\cline { 2 - 3 } & Crisis (C=1) & No Crisis (C=0) \\
\hline Signal Issued $(\mathrm{S}=1)$ & Correct Signal $(\mathrm{A})$ & No Stress Event (B) \\
\hline No Signal Issued $(\mathrm{S}=0)$ & Type I Error (C) & Correct Signal (D) \\
\hline
\end{tabular}

Source: Ito, et al., 2014 in WP/7/2015 BI

In this matrix, $A$ is the number of months in which the indicator issued a good signal, B is the number of months in which the indicator issued a bad signal or "noise", C is the number of months in which the indicator failed to issue a signal (which would have been a good signal), and $D$ is the number of months in which the indicator has refrained from issuing a signal (which would have been a bad signal). It would issue a signal in every month that is to be followed by a crisis (within the next $\mathrm{n}$ months, example 12 months), so that $\mathrm{A}>0$ and $\mathrm{C}=0$, and it would refrain from issuing a signal in every month that is not to be followed by a crisis (within the next $\mathrm{n}$ months, example 12 months), so that $\mathrm{B}=0$ and $\mathrm{D}>0$. For sure, none of the indicators fit the profile of a perfect indicator, but the matrix will be a useful reference to assess how close or how far is each indicator from that profile.

4) Determining Evaluation Criteria

This study employs six evaluation criteria in order to assess the performance of indicators which was identified through crisis-signal framework, as follows:

(1) The proportion of observations correctly called $=\frac{A+D}{(B+D)+(A+C)}$, defined as the proportion that all observations correctly bring information about crisis and not crisis. This implies that the higher proportion occurred will lead to best evaluation criteria.

(2) The noise-to-Signal-Ratio $=\frac{\frac{B}{B+D}}{\frac{A}{A+C}}$, it measures the false signals as a ratio of the good signals issued. The selection rule is to pick the variable or model that minimises the noise to signal ratio (NTS).

(3) The proportion of crises correctly called $=\frac{A}{A+C}$, is defined as the proportion of crisis happened once the signal was issued. Thus, the higher of its proportion would be fitting of a perfect indicator in signaling the crisis. 
(4) The proportion of false alarm of total alarms issued $=\frac{B}{A+B}$, given that, an individual indicator exposes a frequent false signal. Thus, the lower of its proportion would be good to minimise the panic behavior in the markets.

(5) The proportion of crisis given an alarm issued $=\frac{A}{A+B}$, given that, an individual indicator generates different signals. This criterion is to select indicators that can maximise the probability of a crisis, given a signal was issued as alarm.

(6) The proportion of probability of crisis given no alarm issued $=\frac{C}{C+D}$, given the signal is important, an occurence of crisis without signals was extremely reduced or minimised.

5) Determining Signalling Horizon

The Study involves various signaling horizons to be chosen as the fit horizon that can predic the crisis. This signaling horizons are range of period that has ability for anticipating a crisis. Kaminsky (1997) used 24 month signaling horizon. He argued that the longer signaling horizon would enable policy makers to anticipate a crisis. Meanwhile, Bussiere and Fratzscher (2002) set 12 and 18 months as signal horizon. They argued that various time horizons would provide the best achievable trade-off between missing crises and wrong signal. In addition, this paper adds another 3 and 6 months as signaling horizons considering that a crisis is difficult to be predicted. Providing short horizon enables policy makers to react immediately as crisis starts to build up.

6) Determining Thresholds

Describing conditions on the indices that have been established thresholds required one (thresold) making it easier to determine the conditions and steps to be taken. Beginning the formulation by the reference of Bank Indonesia threshold, namely 2 standard deviations (SD), 1,7 SD, and 1,3 SD to construct SHABAR index threshold. Later, the all mentioned thresholds are used to determine the level of resilience in Islamic banking.

Threshold is then translated into 4 conditions: the resilience condition, alert condition out of resilience, warning condition out of resilience, and crisis conditions. 


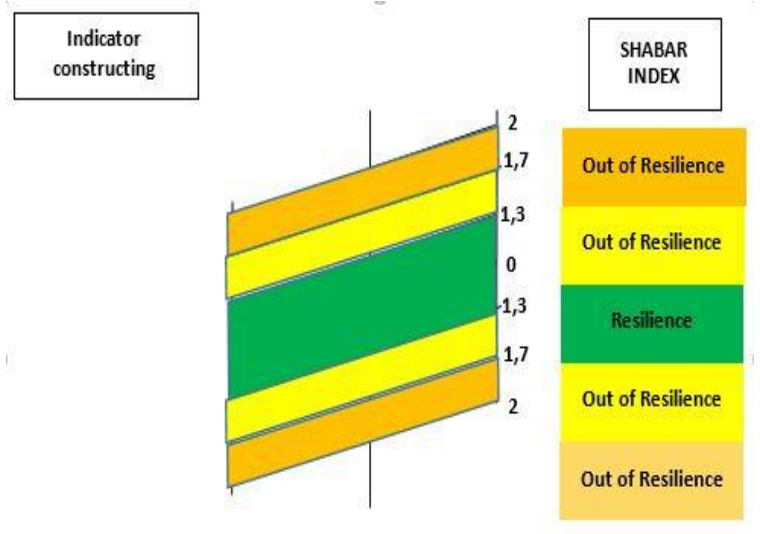

Figure 2.3

SHABAR Index's Threshold

\section{Step 2: Selecting Varibles (Research Variable and Operational Definition)}

This study uses variables derived from all data of IIFS listed in Bank Indonesia. Operational definitions of each variable used in this study are as follows:

\section{Statistical Normalisation approach}

Shari'ah Banking Resilience (SHABAR) Index base year 2011 is used as forming the single index, dimension index, and the main index (SHABAR Index) sequentially. Methodology of calculation using the statistical approach normalisation base year 2011, was formed through the following calculation:

$Q_{t}=\sum_{j=1}^{n} \omega_{j} \frac{x_{t}^{j}-\bar{x}_{(\text {based year })}}{\bar{\sigma}_{(\text {based } \text { year })}}(8)$

Where:

$\mathrm{Q}_{t}$ : Composite Index (single, dimension, main)

$\omega_{t}$ : Weight value of each variable

$x_{t}^{j}$ : Value of variable $x_{t}$ in t-period

$\bar{x}_{\text {based year }}$ : Average variables of $x_{t}$ in 2011

$\bar{\partial}_{2 \text { years }}$ : Standard deviation of of $x_{t}$ in 2011

The period of 2011 base year as a benchmark for Shari'ha banking and financial system of Indonesia on the period experienced a complete regulation after enactment of The Act, which brought adequate regulation for expansion and operation of Islamic banks in a proper way.

\section{Step 3: Imputation of Missing Data}

The data used in this research are secondary data from Bank Indonesia which are categorised as monthly time series data from January 2010 to December 2016. The study period is chosen as a benchmark for Shari ah banking and financial 
system of Indonesia on the period experienced a complete regulation after the enactment of The Act which brought adequate regulation for expansion and operation of IBs in a proper way. This step can be skipped by the availability of adequate data.

\section{Step 4: Normalisation of Data}

Shariah banking resilience (SHABAR) index formed using the statistical normalisation approach base year 2011, when banking performance is in the most sTable level compare to the other years. ${ }^{10}$

\section{Step 5: Weighting and Aggregation for Every Indicators}

The result of normalisation of each indicator (single index) of Islamic banks will be merged into an index with a certain weight (dimension index). Weighting will be determined through variance of the standard deviation of the sample mean to put into strengths in the interpretation of SHABAR Index. The approach is expected to perform the synchronisation between the perceptions of security conditions for IBs and IFIs with the movement of the Index.

The calculation of the weighting method by using variance of the standard deviation can be described in the following formula:

$\operatorname{Var}_{(\text {mean })}=\frac{1}{N} \operatorname{Var}(x)$, where $\partial_{\text {mean }}=\frac{\partial}{\sqrt{N}}(9)$

Where:

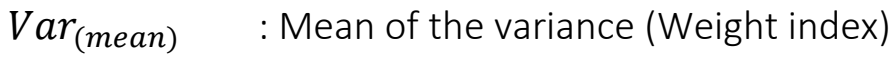

$N \quad$ : Number of observations in the sample used

$\partial_{\text {mean }}$ : Annually standard deviation of the mean of $x_{t}$

$\partial \quad$ : Standard deviation of $x_{t}$

The use of positive and negative sign indicates the direction vector of each indicator against which SHABAR index was formed, the positive influence showed that the higher the pressure on the index and vice versa. Especially, for the index banking intermediation, a positive sign indicates an increase in intermediation and the negative sign indicates a decrease in intermediation.

\section{Step 6: Accuracy Test}

To measure the accuracy of forecasting calibration the probability of resilient uses Quadratic Probability Score (QPS). QPS has a range from 0 to 2, when score $=0$ reflects very accurately with the following formula:

$Q P S=\frac{1}{T} \sum_{t=1} 2\left(P_{t}-R_{t}\right)^{2}$

Where:

10 ibid 
$P=$ Forecasting

$\mathrm{R}=$ Realisation

$\mathrm{T}=$ Period

Meanwhile, the calibration of probability forecasting relates to the accuracy of probability forecasting and the observed relative frequency. Calibration compares the average probability forecast to the average of its realisation. Global Square Bias (GSB) values have ranges from 0 to 2 with score value $=0$ reflecting perfect calibration. The formula is as follows:

$G S B=2(\bar{P}-\bar{R})^{2},(11)$

where $\bar{P}=\frac{1}{T} \sum_{t=1}^{T} P_{t} P$ and

$\bar{P}=\frac{1}{T} \sum_{t=1}^{T} P_{t}$

\section{Step 7: Back to the Details}

Heat map is one of the best visualisation tools for dense point data. They are also useful for doing cluster analysis or hotspot analysis. In this study, heat map or chart indicators with color indication are used as manual to measure vulnerability level of the indicator. Heat map of SHABAR Index show the entire index results in terms of pressure, intermediation and banking efficiency.

For each composite index will be composed of the composite index constituent presence. The use of heat maps is commonplace in all types of risk analysis since they make it easy to see the source of vulnerability. The use of variation colour in heat maps refers to the threshold (treshold). Overall, there are three colors on the heat map SHABAR index, green depicts resilience condition, with colour indicator stands at a better value than the first treshold. Yellow colour (two degradations depict below and upper threshold) depicts alert condition out of resilience threshold. The indicator value in these conditions is between treshold first and treshold second. The orange colour indicates the area of early warning system of crisis before crisis in resiliency of Islamic banks. If it is more than upper threshold or below the lower threshold then it depicts crisis in banking. 


\section{RESULT AND DISCUSSION}

\subsection{Results SHABAR Index with Standardised Normalisation Approach}

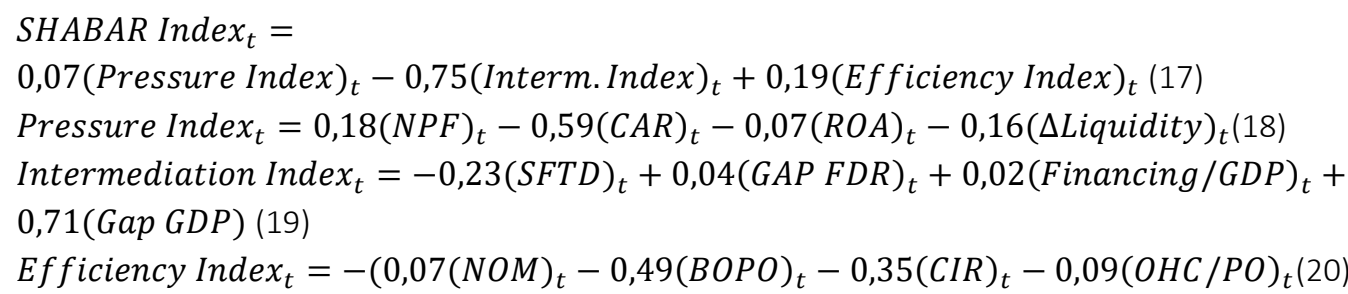

SHABAR Index formation, with a based year approach to statistical normalisation of monthly time series data from January 2010 to December 2016. This is modified by the availability of existing data. After determining the index normalisation method followed by the selection of indicators finally specific weight for each dimension forming SHABAR index is obtained. It is shown in formula (17) to (20) above.

Based on formula (17), pressure index contributes positively $7 \%$ to SHABAR index, while intermediary index contributes negetively 75\% and efficiency index contributes positively $19 \%$. In the formula (18), NPF contributes positively $18 \%$ to the pressure index, while CAR contributes negetively 59\%, ROA contributes negatively $7 \%$, and $\Delta$ liquidity contribute positively $16 \%$. In the formula (19), SFTD contributes negatively $23 \%$ to the intermediary index, while GapFDR contributes positively $4 \%, F / G D P$ contributes positively $2 \%$, and $\Delta$ liquidity contributes positively $71 \%$. Formula (20) shows negative contribution of NOM in the level of $7 \%$ to the efficiency index, BOPO contributes negatively $49 \%, \mathrm{CIR}$ contributes negatively $35 \%$, and $O H C / P O$ contributes negatively $9 \%$. 


\subsection{Result of Accuration Test of SHABAR Index}

\section{Composite Index}

Table 3.1

Test Accuration of SHABAR Index with Upper Treshold

\begin{tabular}{|c|c|c|c|c|c|}
\hline & \multirow[b]{2}{*}{ Items } & & \multicolumn{3}{|l|}{ Threshold } \\
\hline & & & 1,3 & 1,7 & 2 \\
\hline \multirow{7}{*}{ Upper Threshold } & \multirow{5}{*}{ Loss } & 24 month & 0,169109 & 0,086907 & 0,09198 \\
\hline & & 12 month & 0,005556 & 0,033437 & 0,048758 \\
\hline & & 6 month & 0,046784 & 0,057019 & 0,070779 \\
\hline & & 3 month & 0,08538 & 0,080128 & 0,092788 \\
\hline & & current year & 0,106322 & 0,103241 & 0,109259 \\
\hline & QPS & & 73,80952 & 73,80952 & 70,2381 \\
\hline & GSB & & 94,33107 & 92,50283 & 91,14229 \\
\hline
\end{tabular}

Dimension Index

Table 3.2

Test Accuration of SHABAR Index with Lower Treshold

\begin{tabular}{|c|c|c|c|c|c|}
\hline & \multirow[b]{2}{*}{ Items } & & \multicolumn{3}{|l|}{ Threshold } \\
\hline & & & 1,3 & 1,7 & 2 \\
\hline \multirow{7}{*}{$\begin{array}{l}\text { Lower } \\
\text { Threshold }\end{array}$} & \multirow{5}{*}{ Loss } & 24 month & 0,077193 & 0,016667 & 0,016667 \\
\hline & & 12 month & 0,021131 & 0,019591 & 0,019591 \\
\hline & & 6 month & 0,02284 & 0,022121 & 0,022121 \\
\hline & & 3 month & 0,02284 & 0,022121 & 0,022121 \\
\hline & & current year & 0,02284 & 0,022121 & 0,022121 \\
\hline & QPS & & 88,09524 & 94,04762 & 94,04762 \\
\hline & GSB & & 99,94331 & 99,64569 & 99,64569 \\
\hline
\end{tabular}


Table 3.3

QPS and GSB of Dimention Index

\begin{tabular}{|c|c|c|c|c|c|c|c|}
\hline Category & NO & Indicator & Trend & $\begin{array}{l}\text { Loss } \\
(1,3)\end{array}$ & $\begin{array}{l}\text { Threshold 1,3 } \\
\text { Lamdha=1600 } \\
\text { (Bank }\end{array}$ & $\begin{array}{l}\text { Accu } \\
\text { Calib }\end{array}$ & $\begin{array}{l}\text { cy and } \\
\text { tion }\end{array}$ \\
\hline \multirow{11}{*}{$\begin{array}{l}\text { Dimension } \\
\text { Index } \\
(\mu=0,5)\end{array}$} & \multirow{4}{*}{2.1} & \multirow{4}{*}{ Pressure Index } & \multirow{2}{*}{ One Side HPF } & \multirow{2}{*}{0,021} & \multirow{2}{*}{$\begin{array}{l}\text { Upper } \\
\text { Threshold }\end{array}$} & QPS & 82,14 \\
\hline & & & & & & GSB & 99,65 \\
\hline & & & \multirow{2}{*}{ One Side HPF } & \multirow{2}{*}{0,08} & \multirow{2}{*}{$\begin{array}{l}\text { Lower } \\
\text { Threshold }\end{array}$} & QPS & 69,05 \\
\hline & & & & & & GSB & 91,84 \\
\hline & \multirow{4}{*}{2.2} & \multirow{4}{*}{ Intermdiary index } & \multirow{2}{*}{ One Side HPF } & \multirow{2}{*}{0,073} & \multirow{2}{*}{$\begin{array}{l}\text { Upper } \\
\text { Threshold }\end{array}$} & QPS & 65,48 \\
\hline & & & & & & GSB & 95,90 \\
\hline & & & \multirow{2}{*}{ One Side HPF } & \multirow{2}{*}{0,017} & \multirow{2}{*}{$\begin{array}{l}\text { Lower } \\
\text { Threshold }\end{array}$} & QPS & 85,71 \\
\hline & & & & & & GSB & 97,96 \\
\hline & \multirow{3}{*}{2.3} & \multirow{3}{*}{ Efficiency Index } & \multirow{2}{*}{ One Side HPF } & \multirow{2}{*}{0,06} & \multirow{2}{*}{$\begin{array}{l}\text { Upper } \\
\text { Threshold }\end{array}$} & QPS & 82,14 \\
\hline & & & & & & GSB & 99,31 \\
\hline & & & One Side HPF & 0,117 & $\begin{array}{l}\text { Lower } \\
\text { Threshold }\end{array}$ & QPS & 80,95 \\
\hline
\end{tabular}

Table 4.1 and 4.2 explain the result of accuration test for SHABAR index with upper and lower threshold, the resuts are as follows:

a. The smallest loss value for upper threshold is 0,005556 which occurs at 12 months' prediction months with threshold 1.3.

b. The smallest Lloss value for the lower threshold is 0.016667 which occurs on the 24 months' prediction month with the threshold of 1.7 and 2

c. The smallest loss value for the threshold is 0,005556 which occurs at prediction month 12 months with threshold 1.3

d. The largest percentage of QPS for upper threshold is 73,80952 which occurs at threshold 1.3 and 1.7

e. The largest percentage of QPS for the lower threshold of 94.04762 occurs at the threshold of 1.7 and 2

f. The largest percentage of GSB for upper threshold is 94.33107 occurs at threshold 1.3

g. The percentage of GSB is the same for each level $(1.3,1.7$ and 2$)$ in the lower threshold

Table 4.3 shows the results of accuration test of every dimension index constructing SHABAR index. The red colour shows the accuracy below the standard, while the others are in it track. Generally, all constucted dimentions' index shows good accuracy performance of more than $66,67 \%$. The dimension index that shows less accuracy performance is intermediary index which has QPS level only $65,48 \%$. 


\section{Single Index}

Table 3.4

QPS and GSB of Dimention Index

\begin{tabular}{|c|c|c|c|c|c|c|c|}
\hline Category & NO & Indicator & Trend & Loss & $\begin{array}{c}\text { Threshold 1,3 } \\
\text { Lamdha=1600 } \\
\text { (Bank Indonesia) }\end{array}$ & \multicolumn{2}{|c|}{$\begin{array}{c}\text { Accuracy and } \\
\text { Calibration }\end{array}$} \\
\hline \multirow{39}{*}{$\begin{array}{l}\text { Single } \\
\text { Index } \\
(\mu=0,5)\end{array}$} & \multirow{4}{*}{3.1} & \multirow{2}{*}{ NPF } & \multirow{2}{*}{ One Side HPF } & \multirow{2}{*}{0,048} & \multirow{2}{*}{ Upper Threshold } & QPS & 91,66667 \\
\hline & & & & & & GSB & 99,30556 \\
\hline & & \multirow{2}{*}{ NPF } & \multirow{2}{*}{ One Side HPF } & \multirow{2}{*}{0,074} & \multirow{2}{*}{ Lower Threshold } & QPS & 89,28571 \\
\hline & & & & & & GSB & 99,98583 \\
\hline & \multirow{4}{*}{3.2} & \multirow{2}{*}{ ROA } & \multirow{2}{*}{ One Side HPF } & \multirow{2}{*}{0,061} & \multirow{2}{*}{ Upper Threshold } & QPS & 78,57143 \\
\hline & & & & & & GSB & 97,95918 \\
\hline & & \multirow{2}{*}{ ROA } & \multirow{2}{*}{ One Side HPF } & \multirow{2}{*}{0,09} & \multirow{2}{*}{ Lower Threshold } & QPS & 72,61905 \\
\hline & & & & & & GSB & 93,75 \\
\hline & \multirow{4}{*}{3.3} & \multirow{2}{*}{ CAR } & \multirow{2}{*}{ One Side HPF } & \multirow{2}{*}{0,022} & \multirow{2}{*}{ Upper Threshold } & QPS & 95,2381 \\
\hline & & & & & & GSB & 99,94331 \\
\hline & & $\cos ^{-1}$ & One cida tor & זר 0 ז & Lom Throch & QPS & 46,42857 \\
\hline & & CAK & Une side nis? & $0, \angle 3$ & Lower Inreshold & GSB & 84,56633 \\
\hline & & $\Delta 1$ & Ono Sido HPE & 0036 & Hnner Throchold & QPS & 80,95238 \\
\hline & 34 & $\Delta \mathrm{L}$ & 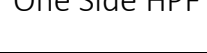 & 0,050 & Upper mirestrotu & GSB & 98,58277 \\
\hline & 0.4 & $\Lambda 1$ & One Side HPE & 0098 & I ower Threshold & QPS & 75 \\
\hline & & $\Delta \mathrm{L}$ & Une slae hrF & 0,098 & Lower inrestiona & GSB & 94,88379 \\
\hline & & SETD & One Side HPF & 0.094 & Unoer Threshold & QPS & 66,66667 \\
\hline & & & & & & GSB & 90,4195 \\
\hline & J.J & SETD & One Side HPE & 0025 & L ouror Throchold & QPS & 84,52381 \\
\hline & & SFID & Une slae hip & $0,0<3$ & Lower inrestiota & GSB & 97,60488 \\
\hline & & $G \cap \cap E D R$ & One Sido HPE & 005 & Unner Throchold & QPS & 83,33333 \\
\hline & 36 & GaprDR & Une slae HPF & 0,095 & upper inresnold & GSB & 98,58277 \\
\hline & & $G=n E \cap R$ & One Cidn HDF & ב 120 & Lowor Throchold & QPS & 63,09524 \\
\hline & & GapruK & Une slae hip & $0,1 \angle L$ & Lower inresnota & GSB & 94,88379 \\
\hline & & קח & One Cidn HDE & 0025 & Unner Throshold & QPS & 98,80952 \\
\hline & 7 & GUP & Une slae nis & $0,0 \angle 3$ & upper inrestiota & GSB & 99,98583 \\
\hline & 0.1 & GanG & One Side HPE & 0017 & I ower Threchold & QPS & 100 \\
\hline & & Gapour & ? & 0,017 & Lover tili estrutu & GSB & 100 \\
\hline & & Sח & Onecida tor & 0001 & Hno re Throchold & QPS & 63,09524 \\
\hline & 28 & GUP & Une slae nip & 0,081 & upper mirestuda & GSB & 88,08107 \\
\hline & 3.8 & GanGDP & One Side HPE & 1 010 & Iower Threchold & QPS & 82,14286 \\
\hline & & & & & & GSB & 99,30556 \\
\hline & & NOM & One Side HPF & 0.058 & Unner Threshold & QPS & 76,19048 \\
\hline & 30 & & & & & GSB & 99,94331 \\
\hline & 0.9 & NOM & One side HPF & 0.108 & Lower Threshold & QPS & 66,66667 \\
\hline & & & & & & GSB & 90,4195 \\
\hline & & 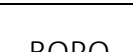 & One Cidn HDF & 0080 & Unnor Throchold & QPS & 80,95238 \\
\hline & 3.10 & DUru & क्ष & 0,000 & 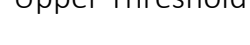 & GSB & 97,22222 \\
\hline & & BOPO & One Side HPF & 0,027 & Lower Threshold & QPS & 77,38095 \\
\hline
\end{tabular}




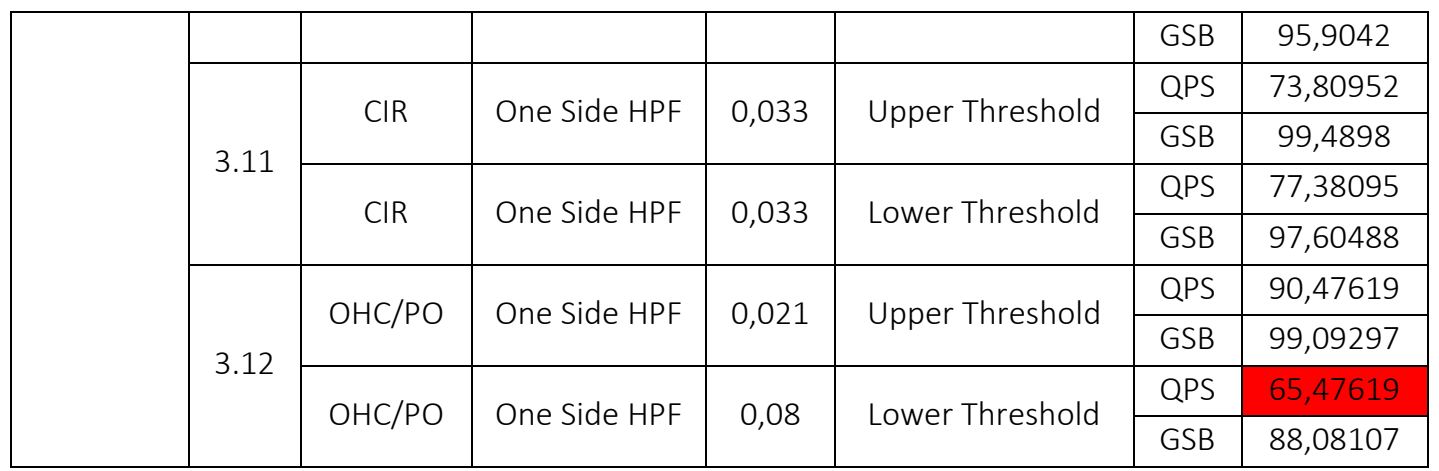

Table 3.4 shows the results of accuration test of every single index constructing SHABAR index. The red colour shows the accuracy below the standard, while the others are in it track. Generally, all indicators show good accuracy performance more than $66,67 \%$. The single indices that show less accuracy performance are lower threshold of CAR, GapFDR, NOM, and OHC/PO, while the upper one is SFTD. CAR has QPS level only 46,43\%, GapFDR has 63\%, NOM has 66,67\%, and $\mathrm{OHC} / \mathrm{PO}$ has $65,48 \%$. SFTD has only QPS level of $66,67 \%$.

\subsection{Resilience Level of SHABAR Index}

\section{Composite Index}

Table 3.5

Resilience Level of Composite Index(Cl)

\begin{tabular}{|l|l|c|c|c|c|}
\hline NO & \multicolumn{1}{|c|}{ Indicator } & $\begin{array}{c}\text { Probability of } \\
\text { Systemic Risk (C } \\
\text { \& B) }\end{array}$ & \multicolumn{2}{|l|}{ Threshold (index) } & $\begin{array}{c}\text { Resilience } \\
\text { Level }\end{array}$ \\
\hline 1.1 & SHABAR Index/Cl & 0,03 & Upper & 4,4 & 0,994 \\
\hline 1.2 & SHABAR Index/Cl & 0,07 & Lower & 3,2 & 0,979 \\
\hline
\end{tabular}

Table 4.5 shows the resilience level of SHABAR Index. For SHABAR index itself, resilience level of composite index $(\mathrm{Cl})$ exists in the range level of 0,979 to 0,994 with upper threshold 4,4 and lower threshold 3,2. Probability level of systemic risk occurred $3 \%$ only for upper threshold, while it is $7 \%$ for lower threshold of all crisis possibilities based on sample. 


\section{Dimention Index}

Table 3.6

Resilience Level of Dimension Index

\begin{tabular}{|c|l|c|c|c|c|}
\hline \multirow{2}{*}{ NO } & \multicolumn{1}{|c|}{ Indicator } & $\begin{array}{c}\text { Probability of } \\
\text { Systemic Risk (C \& } \\
\text { B) }\end{array}$ & \multicolumn{2}{|c|}{ Threshold (index) } & Resilience Level \\
\hline \multirow{2}{*}{2.1} & Pressure Index & 0,07 & Upper & 0,1 & 0,979 \\
\cline { 2 - 6 } & Pressure Index & 0,42 & Lower & 0,0 & 0,920 \\
\hline \multirow{2}{*}{2.2} & Intermdiary index & 0,33 & Upper & 6,3 & 0,927 \\
\cline { 2 - 6 } & Intermdiary index & 0,03 & Lower & 4,4 & 0,983 \\
\hline \multirow{2}{*}{2.3} & Efficiency Index & 0,20 & Upper & $-0,3$ & 0,945 \\
\cline { 2 - 6 } & Efficiency Index & 0,23 & Lower & $-1,7$ & 0,974 \\
\hline
\end{tabular}

Table 4.6 shows the resilience level of dimension index constructing $\mathrm{Cl}$. Resilience level of pressure index exists in the range level of 0,920 to 0,979 with upper threshold 0,0 and lower threshold 0,1. Probability level of systemic risk occured $7 \%$ for upper threshold, while it is $43 \%$ for lower threshold of all crisis possibilities based on sample.

While resilience level of intermediary index exists in the range level of 0,927 to 0,983 with upper threshold 4,4 and lower threshold 6,3. Probability level of systemic risk occurred 33\% for upper threshold and 3\% for lower threshold of all crisis possibilities based on sample.

Last but not the least, resilience level of efficiency index exists in the range level of 0,945 to 0,974 with upper threshold $-1,7$ and lower threshold $-0,3$. Probability level of systemic risk occurred 20\% for upper threshold and 23\% for lower threshold of all crisis possibilities based on sample. 
Table 3.7

Resilience Level of Single Index

\begin{tabular}{|c|c|c|c|c|}
\hline \multicolumn{5}{|c|}{ Components of Pressure Index } \\
\hline No & Indicator & $\begin{array}{c}\text { Probability of } \\
\text { Systemic Risk (C \& } \\
\text { B) }\end{array}$ & $\begin{array}{c}\text { Threshold } \\
\text { (index) }\end{array}$ & $\begin{array}{c}\text { Resilience } \\
\text { Level }\end{array}$ \\
\hline $3 \mathrm{~A}$ & NPF & 0,10 & 0,4 & 0,953 \\
\hline $3 \mathrm{~A}$ & NPF & 0,15 & $-0,7$ & 0,926 \\
\hline $4 \mathrm{~A}$ & ROA & 0,25 & 0,4 & 0,939 \\
\hline $4 \mathrm{~A}$ & $\mathrm{ROA}$ & 0,28 & 0,0 & 0,910 \\
\hline $5 \mathrm{~A}$ & CAR & 0,08 & $-0,7$ & 0,978 \\
\hline $5 \mathrm{~A}$ & CAR & 0,50 & $-0,9$ & 0,750 \\
\hline $6 \mathrm{~A}$ & $\Delta \mathrm{L}$ & 0,08 & 0,5 & 0,964 \\
\hline $6 \mathrm{~A}$ & $\Delta \mathrm{L}$ & 0,35 & $-0,4$ & 0,902 \\
\hline \multicolumn{5}{|c|}{ Components of Intermediary Index } \\
\hline & SFTD & 0,33 & $-0,3$ & 0,906 \\
\hline & SFTD & 0,17 & $-0,6$ & 0,975 \\
\hline & GapFDR & 0,22 & 0,4 & 0,905 \\
\hline & GapFDR & 0,23 & 0,1 & 0,878 \\
\hline & F/GDP & 0,05 & 1,8 & 0,975 \\
\hline & F/GDP & 0,03 & $-0,8$ & 0,983 \\
\hline & GapGDP & 0,18 & 8,9 & 0,919 \\
\hline & GapGDP & 0,07 & 6,3 & 0,979 \\
\hline \multicolumn{5}{|c|}{ Components of Efficiency Index } \\
\hline & NOM & 0,20 & 0,7 & 0,942 \\
\hline & NOM & 0,45 & 0,6 & 0,892 \\
\hline & $\mathrm{BOPO}$ & 0,30 & 0,2 & 0,912 \\
\hline & BOPO & 0,27 & $-0,4$ & 0,973 \\
\hline & $\mathrm{CIR}$ & 0,07 & $-1,1$ & 0,967 \\
\hline & $\mathrm{CIR}$ & 0,07 & $-4,3$ & 0,967 \\
\hline & OHC.PO & 0,07 & $-0,3$ & 0,979 \\
\hline & OHC.PO & 0,23 & $-0,6$ & 0,920 \\
\hline
\end{tabular}

Table 4.7 shows the resilience level of single index constructing $\mathrm{Cl}$. From pressure's side, resilience level of NPF exists in the range level of 0,926 to 0,953 with upper threshold 0,4 and lower threshold -0,7. Probability level of systemic risk occurred $10 \%-15 \%$ of all crisis possibilities based on sample. 
Resilience level of ROA exists in the range level of 0,910 to 0,939 with upper threshold 4,4 and lower threshold 6,3. Probability level of systemic risk occurred $25 \%-28 \%$ of all crisis possibilities based on sample. Resilience level of CAR exists in the range level of 0,950 to 0,978 with upper threshold 0 and lower threshold $-0,7$. Probability level of systemic risk occurred $8 \%-50 \%$ of all crisis possibilities based on sample. Resilience level of $\Delta \mathrm{L}$ exist in the range level of 0,902 to 0,964 with upper threshold 0,5 and lower threshold $-0,4$. Probability level of systemic risk occurred $8-35 \% \%$ of all crisis possibilities based on sample.

From intermediary side, resilience level of SFTD exists in the range level of 0,906 to 0,975 with upper threshold $-0,6$ and lower threshold $-0,3$. Probability level of systemic risk occurred $17-33 \% \%$ of all crisis possibilities based on sample. Resilience level of GapFDR exists in the range level of 0,878 to 0,905 with upper threshold 0,4 and lower threshold 0,1. Probability level of systemic risk occurred $22 \%-23 \%$ of all crisis possibilities based on sample. Resilience level of F/GDP exists in the range level of 0,975 to 0,983 with upper threshold 1,8 and lower threshold 0,8 . Probability level of systemic risk occurred $3 \%-5 \%$ of all crisis possibilities based on sample.Resilience level of GapGDP exists in the range level of 0,919 to 0,979 with upper threshold 8.9 and lower threshold 6,3. Probability level of systemic risk occurred $7-18 \% \%$ of all crisis possibilities based on sample.

From efficiency side, resilience level of NOM exists in the range level of 0,892 to 0,942 with upper threshold 0,7 and lower threshold 0,6. Probability level of systemic risk occurred $20-45 \%$ of all crisis possibilities based on sample. Resilience level of BOPO exists in the range level of 0,912 to 0,973 with upper threshold 0,2 and lower threshold -0,4. Probability level of systemic risk occurred reach $27 \%-30 \%$ of all crisis possibilities based on sample. Resilience level of CIR exist in the level of 0 , with upper threshold $-1,1$ and lower threshold $-4,3$. Probability level of systemic risk happen reach $7 \%$ of all crisis possibilities based on sample.Resilience level of $\mathrm{OHC} / \mathrm{PO}$ exist in the range level of 0,920 to 0,979 with upper threshold $-0,3$ and lower threshold -0,6. Probability level of systemic risk happen reach $7 \%-23 \%$ of all crisis possibilities based on sample. 


\section{Threshold Single Index}

Table 3.8

Upper and Lower Treshold of Indicators

\begin{tabular}{|l|r|r|r|r|r|r|}
\hline \multirow{2}{*}{ Indicator } & \multicolumn{3}{|c|}{ Upper Threshold } & \multicolumn{3}{c|}{ Lower Threshold } \\
\cline { 2 - 7 } & Th 1,3 & Th 1,7 & \multicolumn{1}{c|}{ Th 3 } & Th 1,3 & \multicolumn{1}{c|}{ Th 1,7 } & \multicolumn{1}{c|}{ Th 3 } \\
\hline NPF & 0,38 & 0,55 & 0,68 & $-0,71$ & $-0,88$ & $-1,00$ \\
\hline ROA & 0,38 & 0,44 & 0,48 & 0,04 & $-0,02$ & $-0,06$ \\
\hline CAR & $-0,67$ & $-0,63$ & $-0,61$ & $-0,88$ & $-0,92$ & $-0,94$ \\
\hline$\Delta \mathrm{L}$ & 0,46 & 0,59 & 0,69 & $-0,41$ & $-0,54$ & $-0,64$ \\
\hline SFTD & $-0,29$ & $-0,24$ & $-0,20$ & $-0,62$ & $-0,67$ & $-0,71$ \\
\hline Gap FDR & 0,44 & 0,49 & 0,52 & 0,14 & 0,09 & 0,06 \\
\hline F/GDP & 1,83 & 2,24 & 2,54 & $-0,81$ & $-1,21$ & $-1,52$ \\
\hline Gap FDR & 8,95 & 9,36 & 9,66 & 6,28 & 5,88 & 5,57 \\
\hline NOM & 0,69 & 0,70 & 0,70 & 0,63 & 0,62 & 0,61 \\
\hline BOPO & 0,19 & 0,28 & 0,35 & $-0,40$ & $-0,49$ & $-0,56$ \\
\hline CIR & $-1,14$ & $-0,66$ & $-0,30$ & $-4,25$ & $-4,73$ & $-5,09$ \\
\hline OHC/PO & $-0,32$ & $-0,27$ & $-0,23$ & $-0,65$ & $-0,70$ & $-0,74$ \\
\hline
\end{tabular}

From the above, we can see the results of upper and lower threshold of every single indicator constructing SHABAR index. Threshold 1,3 used as a basis to determined resilience level because it is the most low threshold which contributed to the loss level in Shari'ah banking.

\subsection{Trace Back by Using Heat Map}

One of the weaknesses in the indexation of the indicators is difficulty of tracing back to see the source of the pressure on the index. Heat maps are one of the best visualisation tools for dense point data. They are also useful for conducting cluster analysis or hotspot analysis. In this study, heat maps or chart indicators with colour indication serve as manual vulnerability level of the indicator. Heat maps of SHABAR index show the entire index results in terms of pressure, intermediation and banking efficiency.

Each composite index will be composed of the composite Index constituent, presence Heat Map make easy see the source of vulnerability. The use of variation colour in the heat maps refers to the threshold (treshold). Overall, there are three colours on the heat map SHABAR index. Green colour depicts normal conditions, with colour indicator stands at a better value than the first treshold. Yellow colour depicts the standby state: the indicator value in these conditions is between 
treshold first and second treshold. The orange colour, the standby state, the indicator on this colour is at a value between.

Table 3.9

Heat Map SHABAR Index

(January 2010-December 2016)

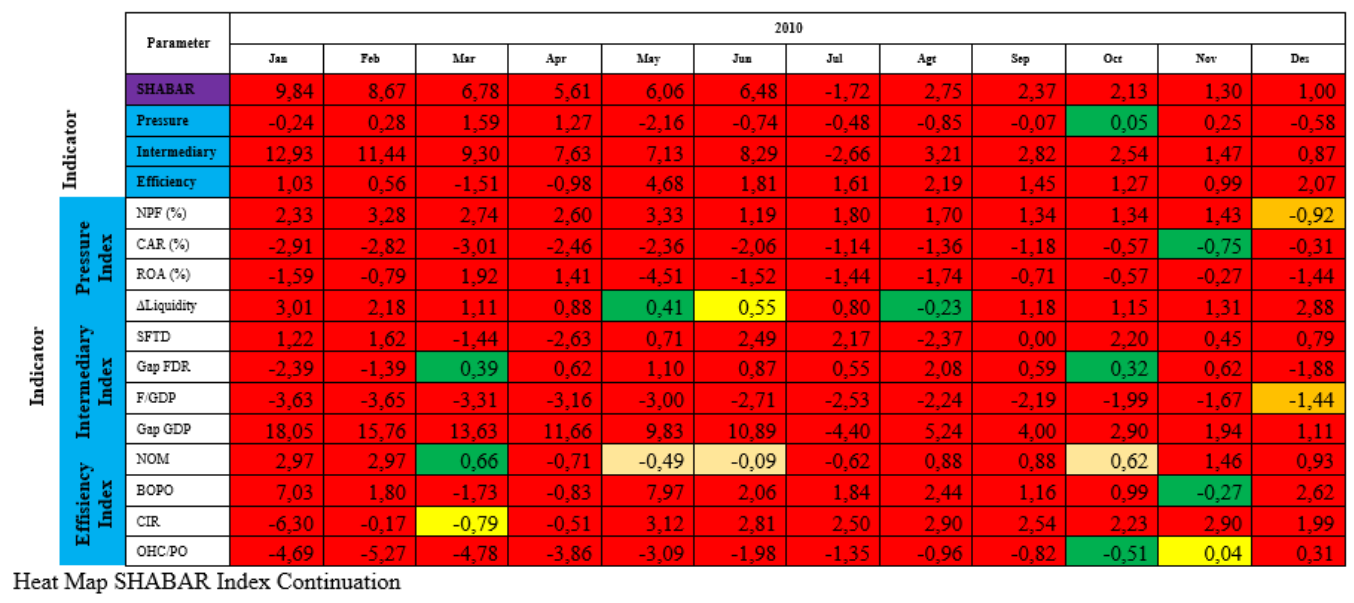

The above heat maps are presented based on the single, dimension, and composite index data that have been formulated in the previous section. These heat maps describe the condition of banking in Indonesia in 2010 after the enactment of The Act. Based on the above mentioned heat maps it appears that the trend of banking conditions in Indonesia is beyond the threshold limit of its ideal level of resilience. Based on business cycle theory, it happen if in the business implementation of Shari'ah banking is too excessive (above upper threshold) or too defensive whereas looking for a safe level (below ideal resistance level).

The average indicator shows its resilience level near the end of 2010. CAR and $\mathrm{BOPO}$ are at their ideal resilience levels in November, while Gap FDR and OHC/PO is in October (?). NPF and F/GDP are at warning level in December (?). While $\Delta$ Liquidity successively is within its ideal resilience level in May and August (?), NOM indicator is in the most frequently alert horizon in 2010 compared to the other variables in May, June, and October. Other yellow horizon indicators occurred in $\mathrm{CIR}$ and $\mathrm{OHC} / \mathrm{PO}$ respectively in March and November. Pressure on banks was at its ideal level of resilience in October. Indicator such as Gap GDP, SFTD, and ROA was out of its ideal level of resilience based on threshold 1,3. When it comes to lower economic growth compare to its trend, it could impact to the banking system. Moreover, Shari'ah banking performance seems play in save area looking at lack contributions of ROA to the SHABAR index. 
2011 heat maps explain it appears that the trend of banking conditions in Indonesia has increased its resilience compared to previous year. Shari'ah banking stack in the ideal level of its resilience means it is not too excessive (above upper threshold) or too defensive (below ideal resistance level). Moreover. it is entering 3 years after enactment of the The Act. The socialisation and implementation of regulation seem to be showing positive results.

The average indicators show its resilience level near the end of 2011. CAR and BOPO were at their ideal resilience levels in November in the same year, while Gap FDR and OHC / PO was in October. NPF and F / GDP were at warning level in December. While $\Delta$ Liquidity was successively within its ideal resilience level in May and August. On the other hand, the NOM indicator was in the most frequently alert horizon in 2010 compared to the other variables in May, June, and October in the same year. Other yellow horizon indicators occurred in CIR and $\mathrm{OHC} / \mathrm{PO}$ respectively in March and November. Pressure on bank was at its ideal level of resilience in October.

The contribution of each indicator to the resilience of Shariah banking in Indonesia appeared to spread evenly throughout 2011. The most isgnificant was the F/GDP indicator. which was almost at its ideal resilience level from April to December, 2011. followed by NPF and BOPO indicator that experienced 5 periods of resilience. The most minimal indicators contributing to banking resilience were CAR, ROA, and CIR. Even the GDP GDP did not show the resiliencenya level at all. The 2012 heat maps explain the single, dimension, and composite index data that have been formulated in the previous section. Based on the above heat maps it appears that the trend of banking conditions in Indonesia was beyond the threshold limit of its ideal level of resilience. Based on business cycle theory it possible happen if in the business implementation of Shariah banking is too excessive (above upper threshold) or too defensive whereas looking for a safe level (below ideal resistance level).

The average indicators shows its resilience level near the beginning of 2012. It shows that in February, Shari'ah banking was able to reach its resilience level. Main contribution emerged from intermediary dimension by its F/GDP indicator showed alert horizon and same with OHC/PO. While intermediary contributes to resilience of Shari'ah banks significantly, pressure dimension shows constant and the most frequently reach resilience level.

In this year, there is quite significant decrease in NPF role toward the contribution to SHABAR index. It is also happened to ROA and Gap FDR which did not 
significantly contribute to SHABAR index throughout the year 2012. Generally, indicators contribute to SHABAR index existed in the beginning of 2012 from January to May.

Based on the above heat maps, it appears that the trend of banking conditions in Indonesia was beyond the threshold limit of its ideal level of resilience even it has been categorised as red zone compared to the other years. Based on business cycle theory, it possible happen if in the business implementation of sharia banking is too excessive (above upper threshold) or too defensive whereas looking for a safe level (below ideal resistance level).

Heat Map SHABAR Index Continuation

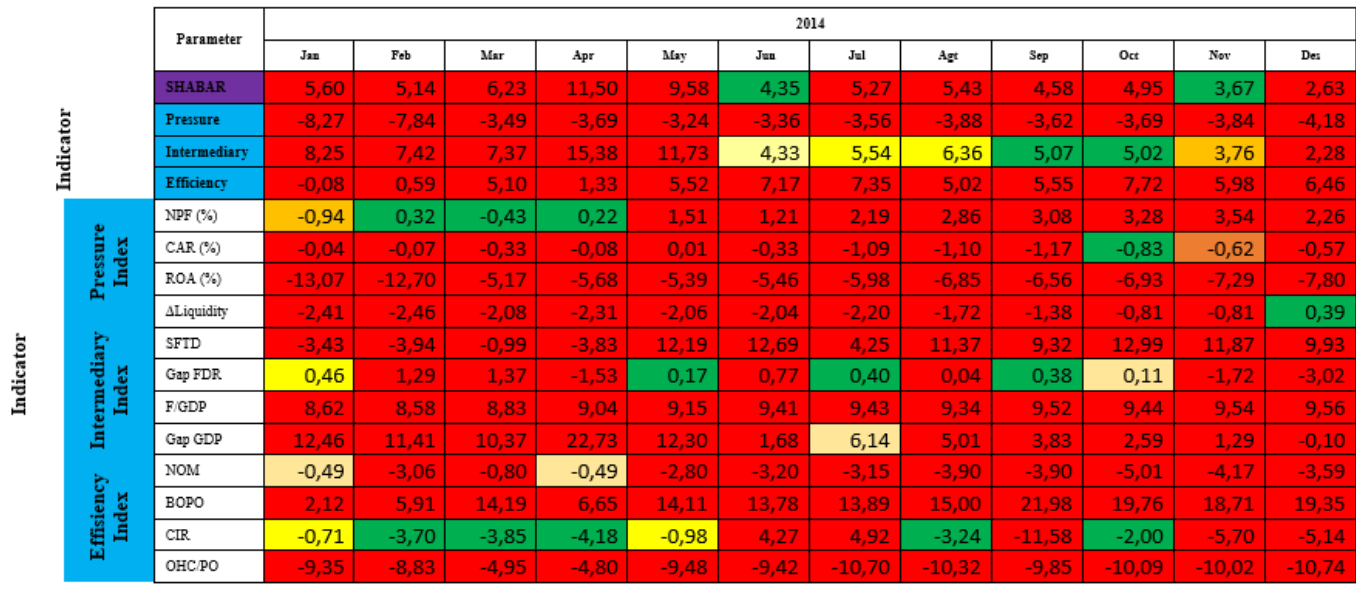

Heat Map SHABAR Index Continuation

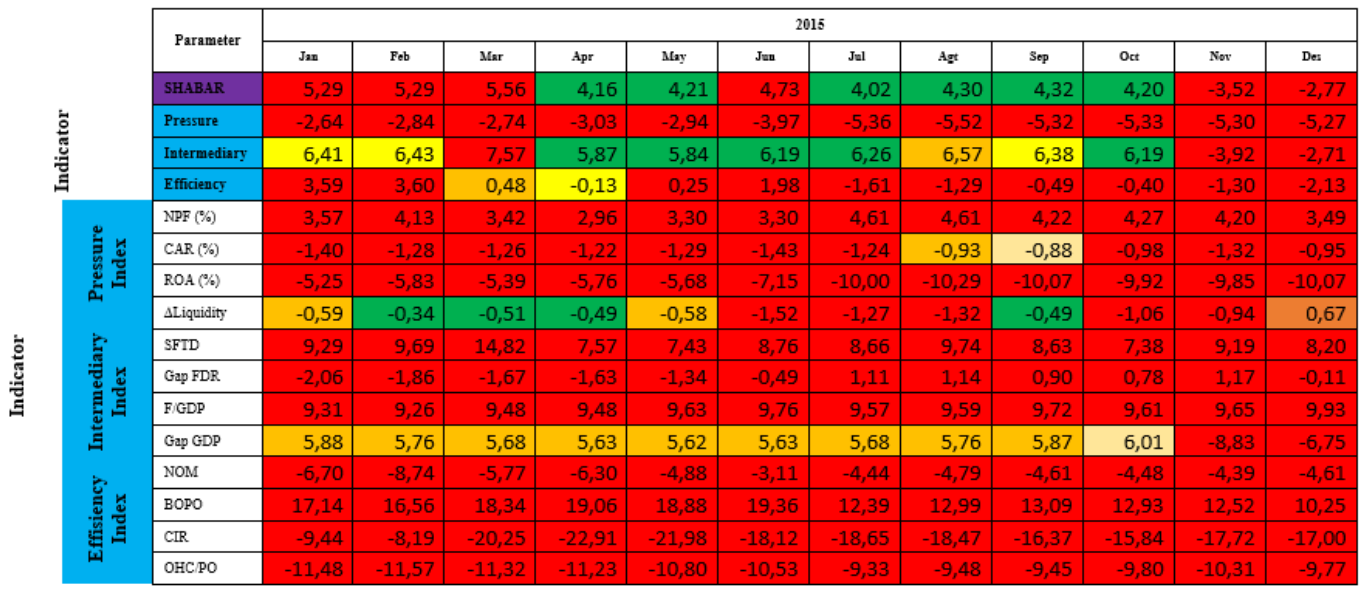

104 | Building The Index Of Resilience For Islamic Banking In Indonesia: A Preliminary Research 


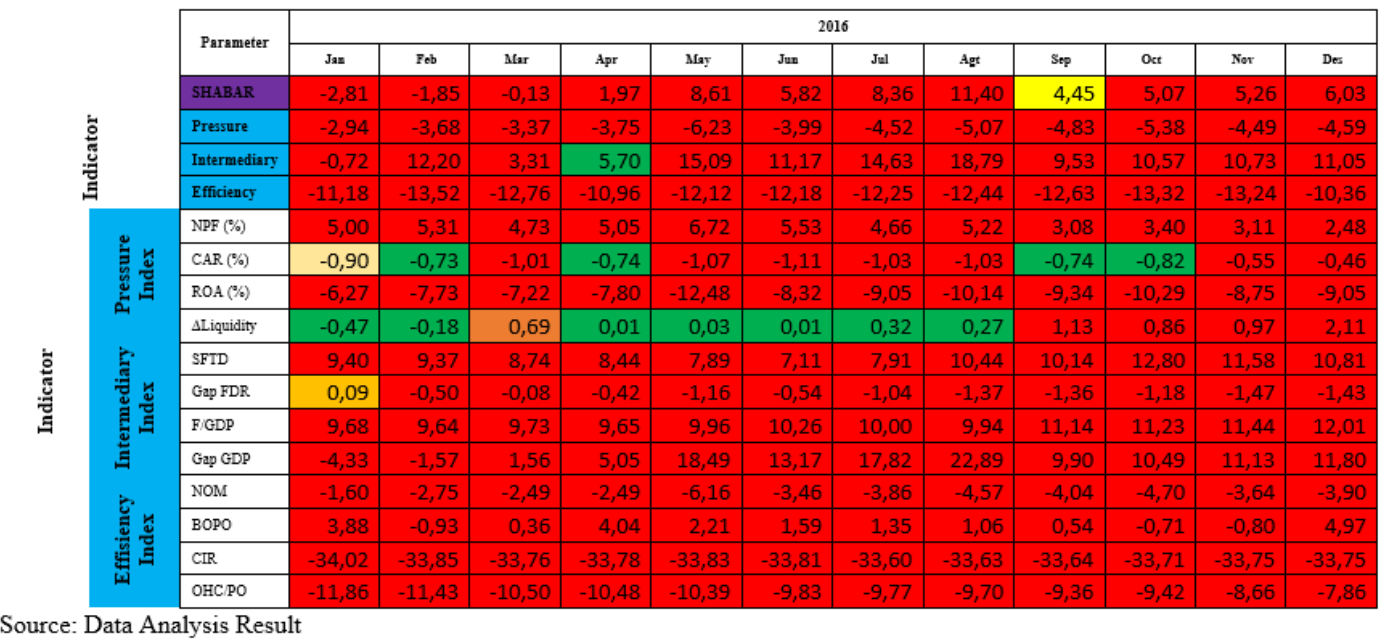

The average indicators showed its resilience level near the end of 2013. Intermediary dimension showed its lack contribution throughout 2013.Contributions made by NPF, CAR, SFTD, NOM, BOPO mainly in the end of the year. While rest of the indicators that did not not have any green or even yellow area at all, that means those lack the conribution. When it comes to lower economic growth compared to its trend, it could impact to the banking system. Moreover, sharia banking performance seems play in save area looking at lack contribution of ROA to the SHABAR index.

The above heat maps are presented based on the single, dimension, and composite index data that have been formulated in the previous section. Based on the above heat map it appears that Shariah banking which had 2 times experiences of conditions in Indonesia was beyond the threshold limit of its ideal level of resilience. Based on business cycle theory it possible happen if in the business implementation of sharia banking is too excessive (above upper threshold) or too defensive whereas looking for a safe level (below ideal resistance level). For the following year, resilience level mostly existed in 2015

\section{CONCLUSION}

Islamic banking operates within the similar financial environment which has been created and facilitated for conventional banking sector. The fundamental differences between the two counterparts call for different treatments in building resilience. The existing literature on banking surveillance tools is either mostly for conventional banking in general, or it is dominated by partial developments. 
Hence, there is a significant gap lies in the literature to address the specificities of Islamic and conventional banking surveillance tools analysis to build resilience that can contribute to financial stability in Indonesia. This study explores to fill in this gap in Indonesian jurisdiction.

The study finds that there are 8 steps to be taken in order for constructing Shari ah banking resilience (SHABAR) index, namely, (1) theoretical framework, (2) data selection, (3) imputation of missing data, (4) normalisation, (5) weighing and aggregation, (6) robustness and sensitivity test, (7) back to the real data, (8) presentation and visualisation.

To conclude, resilience level of Shariah banking in Indonesia exists in spesific ranges as a result of the contributions every single indicator has made towards building required resilience. The future studies may be carried out to run tracking of which indicator enables to contribute to reduce and remove the instability of Shari'ah banking system in Indonesia. 


\section{REFERENCE}

Abubakar A., et al., 2015 "Kerangka dan Analisis Indikator Ketidakseimbangan Keuangan dalam Nasional and Regional Balance Sheet (Version 1), Bank Indonesia

Abubakar A., Rieska I. A., Rini Oktaviani, 2016, "Pemilihan Early Warning Indicator untuk Mengidentifikasi Distress Sektor Korporasi: Upaya Penguatan Crisis Prevention, Bank Indonesia

Alawode, A. A., 2008, "What is Financial Stability", Financial Stability Paper Series Central Bank of Bahrain, March, pp. 16.

Antonio, M. S., 2001, Bank Syariah: Dari Teori ke Praktik, Second edition, Gema Insani, Jakarta.

Asfari, D. D., 2015, "Analisis Financial Stress Indicator Sebagai Alat Ukur Stabilitas Sektor Keuangan Indonesia", Bina Ekonomi, Vol. 19, pp. 18-21.

Ascaria, et al. 2016, "Conseptual Proposal for Future Macroprudential Framework Under a Dual Financial System in Indonesia", Springer International Publishing, Switzerland.

Bank Indonesia, 2016, "Mitigasi Risiko Sistemik untuk Menjaga Stabilitas Sistem Keuangan dan Mendorong Intermediasi di Tengah Tantangan Global dan Domestik, Kajian Stabilitas Keuangan, March.

Bailey, K., 1994, Methods of Social Research, Fourth edition, The Free Press, New York.

BIS, 2009, "Strengthening the Resilience of the Banking Sector", Consultative Document $B C B S$, December.

Blaikie, N., 2003, Analyzing Quantitative Data, Sage Publication, London.

Chattha, J. A., 2015, Assessing the Stability and Resilience of Islamic Banks through Stress Testing under a Standardized Approach of the IFSB Capital Adequacy Framework.

(A. O. Hatem A. El-Karanshawy, Ed.) Bloomsburry Qatar Foundation Journal,Vol. 5, pp. 4-5.

EY, 2016, World Islamic Banking Competitiveness Report 2016.

Farahani, Guzardi et al, 2012, Analysis of Islamic Bank's Financing and Economic Growth :

Case Study Iran and Indonesia, Journal of Economic Cooperation and Development, pp. 1-24.

Gunadi I., et al. 2012, "Pengembangan Bank Indonesia Indeks Stabilitas Keuangan (BISK)".

Gunadi I., Aditya A. T., Cicilia A.H., 2013, "Indeks Stabilitas Sistem Keuangan (ISSK) Pelaksanaan Surveilans Makroprudensial", Working Paper Bank Indonesia.

Harun, A. Cicilia, Sagita Rahmanira, R. Renanda Nathan, 2017, "Systemic Risk Measurement Framework", Article 1 FSR (Financial Stability Review) Bank Indonesia No. 27, September, Jakarta.

Holling C.S., "Resilience ad Stability of Ecological System". Annual Review of Ecological System, Vol. 4, pp. 1-23.

http://www.oecd.org

IFSB, 2015, Islamic Financial Service Industry Stability Report, Kuala Lumpur.

IFSB, 2015, Islamic Financial Service Industry Stability Report, Kuala Lumpur. 
Imaniyati, N. S., 2010, Aspek-Aspek Hukum BMT, First Edition, PT Citra Aditya Bakti, Bandung.

Ismal, Rifky, 2011, The Indonesian Islamic Banking: Theory and Practices, Gramata Publishing, Jakarta.

Karim, A. A., 2008, Islamic Banking Figh and Financial Analysis. Third Edition, PT RajaGrafindo Persada, Jakarta.

Martin Čihák, H. H., 2008, "Islamic Banks and Financial Stability:An Empirical Study". IMF Working Paper. January.

Mejía, Alejandro López, et al., 2014, "Regulation and Supervision of Islamic Banks", IMF Working Paper, December, pp. 5.

OECD, 2005, Handbook on Constructing Composite Indicators: Methodology and User Guide, OECD Publishing. France.

Payne, G., Judy P., 2004, Key Concepts in Social Research. Sage Publication, London.

Pimm, S., 1991, The Balance of Nature? Ecological Issues in the Concervation of Species and Communities, University of Chicago Press, Chicago and London.

Rivai Veithzal, Rifki Ismal, 2013, Islamic Risk Management for Islamic Bank, First edition, PT Gramedia Pustaka Utama. Jakarta.

Republic of Indonesia, 2008, Act of The Republic of Indonesia Number 21 of 2008 Concerning Sharia (Islamic) Banking.

The World Bank, 2009, World Development Indicator, First edition, Green Press Initiative, Washington.

Triono, D. C., 2011, Ekonomi Islam Madzhab Hamfara, Second edition, Irtikaz, Yogyakarta.

Walker, B. C., 2004, Resilience, Adaptability and Transformability in Social-Ecological System. Ecology and Society. Vol. 9. September.

Wijoyo, N. A., 2015, Referensi Risiko Sistemik Perbankan, First edition, UI-Press, Jakarta.

Yuliadi, Imamudin, 2007, Ekonomi Islam Filosofi, Teori dan Implementasi, Second Edition, LPPI UMY, Bantul-DIY 